\title{
Les comptes des consuls de Montferrand (1273-1319), édités par R. Anthony Lodge
}

\section{Walter Meliga}

\section{(2) OpenEdition}

1 Journals

\section{Edizione digitale}

URL: http://journals.openedition.org/studifrancesi/7828

DOI: 10.4000/studifrancesi.7828

ISSN: 2421-5856

\section{Editore}

Rosenberg \& Sellier

\section{Edizione cartacea}

Data di pubblicazione: 1 juillet 2009

Paginazione: 370

ISSN: 0039-2944

\section{Notizia bibliografica digitale}

Walter Meliga, «Les comptes des consuls de Montferrand (1273-1319), édités par R. Anthony Lodge»,

Studi Francesi [Online], 158 (LIII | II) | 2009, online dal 30 novembre 2015, consultato il 13 janvier 2021 URL: http://journals.openedition.org/studifrancesi/7828; DOI: https://doi.org/10.4000/studifrancesi. 7828

Questo documento è stato generato automaticamente il 13 janvier 2021.

\section{(c)}

Studi Francesi è distribuita con Licenza Creative Commons Attribuzione - Non commerciale - Non opere derivate 4.0 Internazionale. 


\section{Les comptes des consuls de Montferrand (1273-1319), édités par R. Anthony Lodge}

Walter Meliga

\section{NOTIZIA}

Les comptes des consuls de Montferrand (1273-1319), édités par R. Anthony LODGE, Paris, École des Chartes, 2006 («Études et rencontres de l'École des Chartes», 23), pp. 213.

1 Secondo volume dell'edizione dei conti degli archivi medievali di Montferrand, dopo il primo del 1985 (Le plus ancien registre de comptes des consuls de Montferrand en provençal auvergnat. 1259-1272, Clermont-Ferrand, 1985), con il quale R. Anthony Lodge prosegue la pubblicazione di una delle più ricche fonti archivistiche dell'occitano medievale. L'edizione è di grande interesse storico e soprattutto linguistico, in particolare per la posizione della città di Montferrand, situata nella parte più settentrionale del dominio d'oc, al confine con i dialetti meridionali d'oïl. 